\title{
Tannin profile, antioxidant properties, and antimicrobial activity of extracts from two Mediterranean species of parasitic plant Cytinus
}

Giuseppantonio Maisetta ${ }^{1 *}$ (D), Giovanna Batoni ${ }^{1}$, Pierluigi Caboni ${ }^{2}$, Semih Esin ${ }^{1}$, Andrea C. Rinaldi ${ }^{3}$ and Paolo Zucca ${ }^{3}$

\begin{abstract}
Background: Cytinus is small genus of endophytic parasitic plants distributed in South Africa, Madagascar, and in the Mediterranean region. In the latter area, two species occur, Cytinus hypocistis and C. ruber, distinguished by both morphological characters and ecological traits. We characterized the ethanolic and aqueous extracts obtained from the inflorescences of C. hypocistis and C. ruber collected in Sardinia, Italy, and explored their tannin content, antioxidant properties and antimicrobial activities.

Methods: Total phenolic contents were determined by Folin-Ciocalteu spectrophotometric method. Tannin content was determined by HPLC. Antioxidant activity of the extracts was tested with both electron transfer-based (FRAP, TEAC, DPPH) and spectrophotometric HAT methods (ORAC-PYR). The antimicrobial activities of extracts/ compounds were evaluated using the broth microdilution method. The bactericidal activity was evaluated using the time-kill method. Biofilm formation was evaluated by crystal violet (CV) staining assay.

Results: Characterization of the tannin profile of C. hypocistis and C. ruber revealed a significant amount of gallotannins, in particular 1-O-galloyl- $\beta$-D-glucose. In addition, pentagalloyl-O- $\beta$-D-glucose was present in all extracts, reaching the concentration of $0.117 \mathrm{~g} / \mathrm{kg}$ in the ethanolic extract of $C$. hypocistis. C. hypocistis extracts displayed a strongest antioxidant activity than C. ruber extracts. Three Gram-positive bacterial species tested (Staphylococcus aureus, Staphylococcus epidermidis, Enterococcus faecium) resulted sensitive to both Cytinus extracts, with MICs ranging from 125 to $500 \mu \mathrm{g} / \mathrm{ml}$ for aqueous extracts and from 31.25 to $250 \mathrm{\mu g} / \mathrm{ml}$ for ethanolic extracts; on the contrary, Gram-negative strains (Pseudomonas aeruginosa and Klebsiella pneumoniae) were not affected by Cytinus extracts. Intriguingly, we observed the suppressive activity of ethanolic extracts of C. hypocistis and C. ruber on biofilm formation of $S$. epidermidis. Experiments performed with synthetic compounds indicated that pentagalloyl-O- $\beta$-D-glucose is likely to be one of the active antimicrobial components of Cytinus extracts.
\end{abstract}

Conclusions: These findings show that Cytinus extracts have antimicrobial and antioxidant activities, suggesting a possible application of Cytinus as sources of natural antimicrobials and antioxidants.

Keywords: Cytinus, Antimicrobial, Antioxidant, Tyrosinase inhibitors, Anti-biofilm, Gallotannins

\footnotetext{
* Correspondence: giuseppantonio.maisetta@dps.unipi.it

'Department of Translational Research and New Technologies in Medicine

and Surgery, University of Pisa, Pisa, Italy

Full list of author information is available at the end of the article
}

(c) The Author(s). 2019 Open Access This article is distributed under the terms of the Creative Commons Attribution 4.0 International License (http://creativecommons.org/licenses/by/4.0/), which permits unrestricted use, distribution, and reproduction in any medium, provided you give appropriate credit to the original author(s) and the source, provide a link to the Creative Commons license, and indicate if changes were made. The Creative Commons Public Domain Dedication waiver (http://creativecommons.org/publicdomain/zero/1.0/) applies to the data made available in this article, unless otherwise stated. 


\section{Background}

Secondary metabolites of plants are well known to exert health-promoting effects in humans. Phenolics, in particular, are a vast array of plant-derived substances with diversified biological activities, from antioxidant and anticancer properties up to the ability to inhibit and kill selected pathogenic bacteria [1-3].

Cytinus (Cytinaceae) is a small genus of holoparasitic, nonchlorophyllic plants, with eight recognized species [4]. It grows endophytically, within the tissues of the host plant: flowers are the only visible part, when they emerge from host tissues during the reproductive period (Fig. 1). The genus has a disjunct distribution, with two centers of diversity: one around the Mediterranean and the other in southern Africa and Madagascar [5, 6]. In the Mediterranean area, Cytinus parasitize the roots of two genera of shrub plants, Cistus and Halimium, both belonging to the family Cistaceae [7].

Cytinus has a place in European popular medicine [8], being used traditionally in the treatment of dysentery, for its a stringentand haemostatic qualities, and for soothing the inflammations of the throat and of eyes (see [9] and references therein, [10]). In Sardinia, ethnobotanical surveys conducted in the south-central part of the island ascertained the Cytinus juice was used as an astringent, tonic, and haemostatic substance [11]. "The plant was known for its astringent and tonic properties: the blackish juice, squeezed and condensed, was used to make the concoctions. The astringent property was exploited in places such as Lodè, Lula and Siniscola as anti-hemorrhage, and in Sadali, Seui and Seulo as haemostatic. At Perdasdefogu, the scalp pulp was applied daily on corns and calluses as a scar-healing agent, and on the skin and inflamed mucous membranes as an astringent and anti-inflammatory remedy," reports Atzei [12] on the ethnobotanical uses of Cytinus in Sardinia.

As for many plants used in traditional medicine, the real biological activities of Cytinus are largely unknown or not rigorously measured, and active substances not identified. Previous reports [13, 14], have described antimalarial and antitumoral activities of extracts of $C$. hypocistis (Hypoquisitis, Hipocistide, Melera, Chupamiele, Cytinet, Cytinelle, Ipocisto, Rockrose parasite, Cistenräuber), and preliminarily assessed their antimicrobial, antioxidant, and anti-tyrosinase properties [9]. To extend our knowledge of the chemical composition of Cytinus, and to explore alternative potential medicinal uses of this plant, we here describe the tannin profile and antioxidant properties of extracts of $C$. hypocistis (L.) L. and C. ruber (Fourr.) Fritsch (synonym C. clusii, C. hypocistis subsp. clusii) collected in Sardinia (Figs. 1 and 2), Italy, and describe in detail their antimicrobial and anti-biofilm activities.

\section{Methods \\ Chemicals}

All reagents were of the best commercial grade available and used without further purification. Tannin standards 1 -O-galloyl- $\beta$-D-glucose and penta- $O$-galloyl- $\beta$-D-glucose were purchased from Sigma-Aldrich (Milan, Italy). Ethanol, cyclohexane and dimethyl sulfoxide were analytical grade solvents obtained from Sigma-Aldrich, Fluka (Milan, Italy).

\section{Plant materials}

Cytinus hypocistis and C. ruber were collected in a mountainous area (Sette Fratelli) $30 \mathrm{~km}$ east of Cagliari, Sardinia, Italy, during April 2016 and April 2017. Plants were identified following field guides and identity
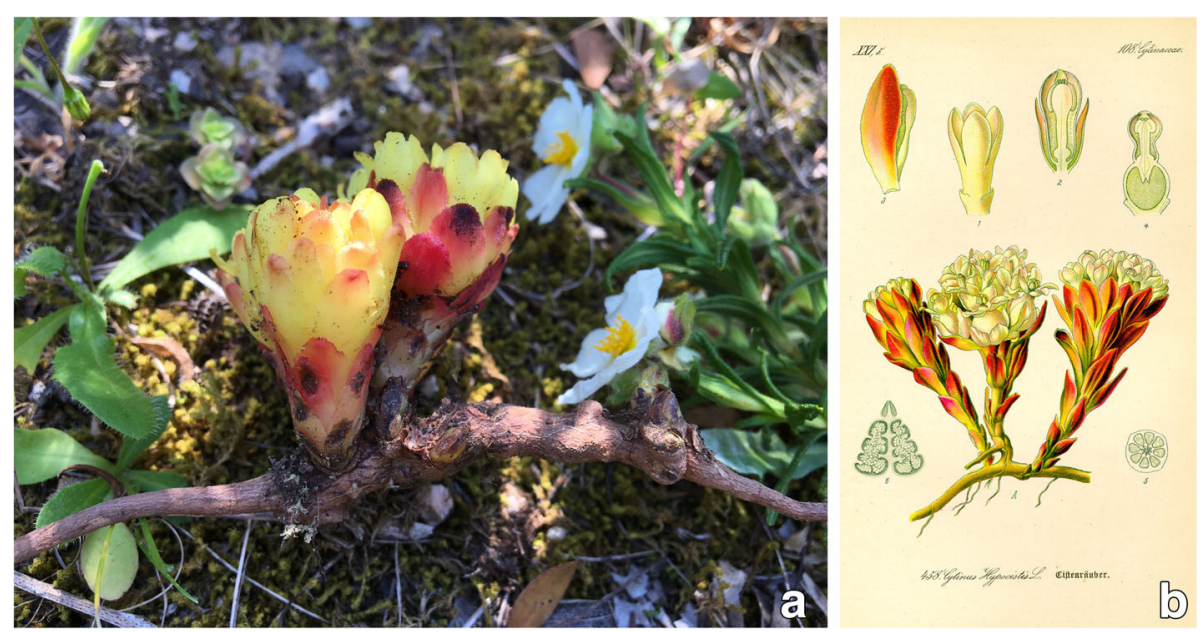

Fig. 1 a Cytinus hypocistis inflorescences, emerging directly from a Cistus monspeliensis' root, Sardinia; (b) A classic portrait of C. hypocistis (from Reference [52]; in the public domain: https://en.wikipedia.org/wiki/Cytinus\#/media/File:Illustration_Cytinus_hypocistis0.jpg) 

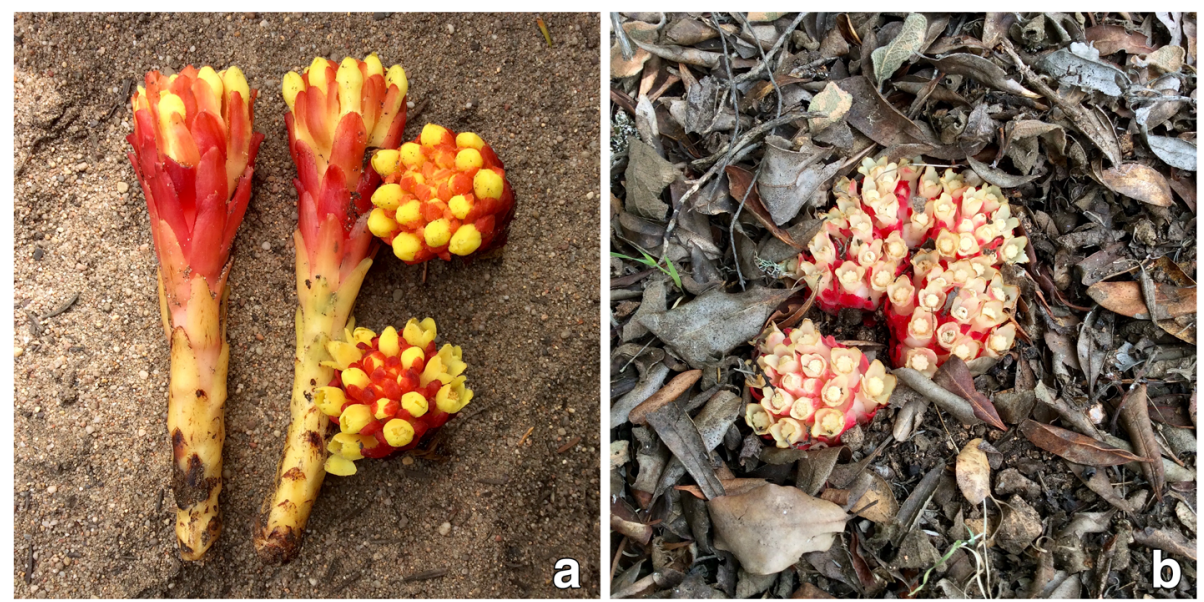

Fig. 2 a Cytinus hypocistis inflorescences, Sardinia; (b) Cytinus ruber inflorescences, Sardinia

confirmed by specialized personnel at the Herbarium of the University of Cagliari, Cagliari, Italy (CAG). Reference material for C. hypocistis (ACR-Cythyp/2016/ 1,ACR-Cythyp/2017/2) and C. ruber (ACR-Cytrub/2016/ 3,ACR-Cytrub/2017/4) is deposited in the collection of the Department of Biomedical Sciences, University of Cagliari. After harvesting, the samples were cleaned, and frozen within $1 \mathrm{~h}$ and then freeze-dried. The samples were grinded afterwards.

\section{Preparation of the extracts}

Samples were resuspended in cyclohexane $(1 \mathrm{~g}$ in $50 \mathrm{~mL}$ solvent). After $30 \mathrm{~min}$ of magnetic stirring at $25^{\circ} \mathrm{C}$, the suspensions were centrifuged at $5000 \mathrm{~g}$ for $10 \mathrm{~min}$. The extraction was repeated 4 times, combining the extracts. Rotary evaporation was used to remove cyclohexane, and to dry the remaining sample. The whole extraction process was then repeated using ethanol, and lastly water as solvents, to obtain three extracts at increasing polarity [9].

\section{Phenolics determination}

Folin-Ciocalteu reagent was used for the spectrophotometric quantification of total phenolics, as already described [15], using an UltroSpec 2100pro (Amersham Bioscience, Milan, Italy). Briefly, $2.5 \mathrm{ml} \mathrm{Na}_{2} \mathrm{CO}_{3} 2 \% w / v$ and $1 \mathrm{ml}$ of each sample were incubated for $1 \mathrm{~min}$ at $25^{\circ}$ C. Then, $45 \mathrm{~min}$ incubation in the dark at $25^{\circ} \mathrm{C}$ with $0.25 \mathrm{ml} 1 \mathrm{~N}$ Folin-Ciocalteu reagent followed. Absorbance at $760 \mathrm{~nm}$ was then recorded. The results were expressed as gallic acid equivalents (mmol GAE). Total flavonoids were quantified using the reaction between sodium nitrite and aluminium chloride [16, 17]. Briefly, $0.25 \mathrm{ml}$ of sample, $1.25 \mathrm{ml} \mathrm{H}_{2} \mathrm{O}$ and $0.075 \mathrm{ml} \mathrm{NaNO}_{2}$ $(5 \% \mathrm{w} / \mathrm{v})$ were incubated for $5 \mathrm{~min}$ at $25^{\circ} \mathrm{C}$, then $0.15 \mathrm{ml}$ $\mathrm{AlCl}_{3}(10 \% \mathrm{w} / \mathrm{v})$ was added. After $6 \mathrm{~min}$, the reaction mixture was alkalinized with $0.5 \mathrm{~mL}$ of $1 \mathrm{M} \mathrm{NaOH}$ and $0.275 \mathrm{ml} \mathrm{H}_{2} \mathrm{O}$. Finally, the absorbance was recorded at $510 \mathrm{~nm}$. Results were expressed as Catechin Equivalent (mmol CE). Differential pH absorbance method was used to quantify total anthocyanins [18]. Briefly, absorbance at $\mathrm{pH} 1.0$ and 4.5 and $510 \mathrm{~nm}$ and $700 \mathrm{~nm}$ were measured. $\mathrm{HCl} / \mathrm{KCl} 0.2 \mathrm{M}$ and sodium acetate $1 \mathrm{M}$ buffers were used to achieve thoss $\mathrm{pH}$ values. Molar extinction coefficient of cyanidin 3-O-glucoside $\left(29,300 \mathrm{M}^{-1} \mathrm{~cm}^{-1}\right)$ was used to calculate total anthocyanin.

$$
[\text { total anthocyanin }]=\frac{\left[\left(A_{510}-A_{700}\right)_{p H 1.0}-\left(A_{510}-A_{700}\right)_{p H 4.5}\right]}{29,300 \mathrm{M}^{-1} \mathrm{~cm}^{-1} \cdot l}
$$

\section{Tannin profile}

The Cytinus extracts dissolved in a $(50: 50 \mathrm{v} / \mathrm{v})$ solution of methanol and water at the concentration of $1000 \mathrm{mg} / \mathrm{l}$ were analyzed by reverse phase HPLC on an Agilent 1200 series HPLC system fitted with an Agilent, Zorbax C18 $(4.6 \times 100 \mathrm{~mm}, 3 \mu \mathrm{m})$. The HPLC conditions were as follows: flow rate, $0.4 \mathrm{ml} / \mathrm{min}$; solvent $\mathrm{A}, 0.1 \%$ formic acid in water; solvent $\mathrm{B}$, methanol; gradient, solvent $\mathrm{B}$ $20-100 \%$ over $10 \mathrm{~min}$ and kept at $100 \%$ for $10 \mathrm{~min}$. The extract was injected $(4 \mu \mathrm{L})$ in the HPLC system and analyzed by ESI-QTOF-MS in the negative mode using an Agilent 6520 time-of-flight mass spectrometer. Mass spectral data were acquired in the range $\mathrm{m} / \mathrm{z} 100-3000$, with an acquisition rate of 1.35 spectra/s, averaging 10,000 transients. The source parameters were adjusted as follows: drying gas temperature $250^{\circ} \mathrm{C}$, drying gas flow rate $5 \mathrm{~L} / \mathrm{min}$, nebulizer pressure $45 \mathrm{psi}$, and fragmentor voltage $150 \mathrm{~V}$. Data acquisition and processing were done using Agilent Mass Hunter Workstation Acquisition v. B.02.00 software. 


\section{Determination of antioxidant capacity}

Three electron-transfer methods were used for the determination of antioxidant power of the samples: 1,1-Diphenyl-2-picrylhydrazyl radical (DPPH) scavenging assay, Ferric Reducing Antioxidant Power (FRAP), and Trolox Equivalent Antioxidant Capacity (TEAC) assay.

DPPH assay involved $30 \mathrm{~min}$ incubation of $0.7 \mathrm{ml}$ of ethanolic $25 \mathrm{mg} / \mathrm{l} \mathrm{DPPH}$ solution and $0.3 \mathrm{~mL}$ of sample. Absorbance at $515 \mathrm{~nm}$ was the measured and converted in DPPH decoloration $\left(\%_{\mathrm{DEC}}\right): \%_{\mathrm{DEC}}=100 \mathrm{x}\left[\left(\mathrm{Abs}_{\mathrm{control}^{-}}\right.\right.$ $\left.\left.\mathrm{Abs}_{\text {sample }}\right) / \mathrm{Abs}_{\text {control }}\right]$. Trolox was used for the calibration curve (linearity range 5-50 $\mu \mathrm{M}$ ) [17]. FRAP method was performed by adding $2.5 \mathrm{ml}$ of $10 \mathrm{mM} \mathrm{2,4,6-tripyri-}$ dyl-s-triazine (TPTZ) in $40 \mathrm{mM} \mathrm{HCl}, 25 \mathrm{~mL}$ of $0.1 \mathrm{M}$ sodium acetate buffer (pH 3.6) and $2.5 \mathrm{ml}$ of $20 \mathrm{mM} \mathrm{FeCl}_{3}$. After an incubation at $37^{\circ} \mathrm{C}, 0.03 \mathrm{ml}$ of sample was then treated for $6 \mathrm{~min}$ at $25^{\circ} \mathrm{C}$ with $0.2 \mathrm{ml}$ of this solution and $0.77 \mathrm{ml} \mathrm{H}_{2} \mathrm{O}$. After $10 \mathrm{~min}$ centrifugation at $8000 \mathrm{~g}$ for $10 \mathrm{~min}$, absorbance at $593 \mathrm{~nm}$ was read [19]. Both Trolox and Fe (II) were used for the calibration curves. TEAC assay involved 2,2'-azinobis (3-ethylbenzothiazoline 6-sulphonate) (ABTS) cationic radical. This was synthesized starting from $7 \mathrm{mmol}$ aqueous $\mathrm{ABTS}$ and $2.45 \mathrm{mmol}$ aqueous $\mathrm{K}_{2} \mathrm{~S}_{2} \mathrm{O}_{8}$. After $16 \mathrm{~h}$ reaction at $25^{\circ} \mathrm{C}$, the radical was produced. Before use, the green radical was diluted using sodium phosphate buffer $75 \mathrm{mM}(\mathrm{pH}$ 7.4) to absorbance $0.70 \pm 0.01$ (at $734 \mathrm{~nm}$ ). Then, $0.01 \mathrm{ml}$ of samples were treated with $1 \mathrm{~mL}$ of this ABTS radical. Absorbance at $734 \mathrm{~nm}$ was the recorded after $6 \mathrm{~min}$ reaction at $25^{\circ} \mathrm{C}$ [17], and converted in percentage of ABTS decoloration (\%DEC): $\% \mathrm{DEC}=100 \times\left[\left(\mathrm{Abs}_{\mathrm{control}^{-}}{ }^{-}\right.\right.$ $\left.\mathrm{Abs}_{\text {sample }} / \mathrm{Abs}_{\text {control }}\right]$. Trolox was used for the calibration curve.

One hydrogen atom transfer method was also included in the antioxidant screening: Oxygen Radical Absorbance Capacity-Pyrogallol red (ORAC-PYR) assay. Briefly, $6.6 \mathrm{mM}$ pyrogallol red $(0.75 \mathrm{ml})$ was incubatedat $25^{\circ} \mathrm{C}$ for $10 \mathrm{~min}$ with $0.125 \mathrm{~mL}$ of the sample. Then 0.125

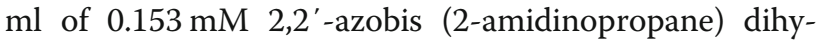
drochloride (APH) was added, recording the decrease in absorbance at $540 \mathrm{~nm}$ for $35 \mathrm{~min}$ at $25^{\circ} \mathrm{C}$. The area under the kinetic curves was determined using Origin Pro software (Origin Lab Corporation, Northampton, Massachusetts, USA): using the area of the blank $\left(\mathrm{AUC}_{\text {blank }}\right): \mathrm{AUC}_{\text {net }}=\mathrm{AUC}_{\text {sample }}-\mathrm{AUC}_{\text {blank }}[16]$. Trolox was used for the calibration curve.

\section{Tyrosinase inhibition}

Tyrosinase inhibition was determined using purified enzyme from Agaricus bisporus [20]. Laccase activity was not presentin the final preparation $(<0.001$ E.U./ml $)$ [21], using syringaldazine as the substrate [22], confirming the absence of contaminant and disturbing activities [23]. 4-tert-Butylcatechol (TBC) was chosen as the substrate, using 4-amino- $N, N$-diethylaniline (ADA) to enhance sensibility [24], in fact these yield a blue adduct upon tyrosinase oxidation, with a maximum wavelength quite far from the extracts. The reaction was performed in the presence of 2 E.U. of enzyme, $50 \mathrm{mM}$ sodium phosphate buffer $\mathrm{pH} 7.0,5 \mathrm{mM}$ TBC, $0.75 \mathrm{mM}$ ADA in a final volume of $1 \mathrm{~mL}$. The absorbance at $625 \mathrm{~nm}\left(\varepsilon_{625}\right.$ $=11,120 \mathrm{M}^{-1} \mathrm{~cm}^{-1}$ ) was followed. One tyrosinase E.U. was the amount of enzyme capable of producing $1 \mu \mathrm{mol}$ of product per minute at $\mathrm{pH} 7$ and $25^{\circ} \mathrm{C}$. The amount of inhibition by the test samples was expressed $\mathrm{IC}_{50}$.

\section{Bacterial strains and culture conditions}

The following bacterial species/strains were used for the study: Staphylococcus aureus (ATCC 33591), Staphylococcus epidermidis (ATCC 35984), Pseudomonas aeruginosa (ATCC 27853), Klebsiella pneumoniae (ATCC BAA-1706) and the clinical isolate Enterococcus faecium VanR 1. For liquid culture, bacteria were grown in Luria Bertani broth (LB), in Mueller Hinton Broth (MHB) or in Tryptone Soy Broth (TSB) (Oxoid, Basingstoke, UK) at $37^{\circ} \mathrm{C}$ with shaking depending on the type of experiment. Enumeration of colony-forming units (CFU) was performed by serially diluting bacterial suspensions and plating them on Tryptone Soy Agar (TSA) (Oxoid). After an incubation of $24 \mathrm{~h}$ at $37^{\circ} \mathrm{C}, \mathrm{CFU}$ were counted.

\section{Broth microdilution assay}

Determination of the minimum inhibitory concentration (MIC) was performed according to standard procedures [25]. Briefly, bacterial strains were grown in Muller-Hinton broth (MHB) until exponential growth phase and diluted with fresh MHB to reach a density of $5 \times 10^{6}$ $\mathrm{CFU} / \mathrm{ml}$. Bacterial suspensions $(10 \mu \mathrm{l})$ were added to 96-well microtiter plates containing $90 \mu \mathrm{l}$ of Cytinus extracts or synthetic galloyl compounds at different concentrations and incubated for $24 \mathrm{~h}$ at $37^{\circ} \mathrm{C}$. DMSO at $2.5 \%$ was used as solvent in the control. The MIC was defined as the lowest concentration of the tested compounds that prevented the visible growth of bacteria.

\section{Bactericidal and time killing assay}

The bactericidal activity of Cytinus extracts and of synthetic penta-O-galloyl- $\beta$-D-glucose was evaluated against S. aureus ATCC 33591 and S. epidermidis ATCC 35984 in sodium-phosphate buffer (SPB, $10 \mathrm{mM}$, pH 7.4) supplemented with $2 \%$ LB (SPLB). Overnight cultures were diluted 1:100 in $\mathrm{LB}$ and then were incubated at $37^{\circ} \mathrm{C}$ to achieve exponential growth phase. The suspensions were then diluted in SPLB to reach a density of $1 \times 10^{7} \mathrm{CFU} /$ $\mathrm{ml}$. To identify the bactericidal concentrations of the extracts in SPLB, in preliminary experiments a volume of $10 \mu \mathrm{l}$ of the bacterial suspensions was added to $90 \mu \mathrm{l}$ of SPLB containing different concentrations of $C$. hypocistis 
or C. ruber extract. Bacteria suspended in SPLB alone were used as cell viability control. For the time killing assays, test samples were incubated with the identified concentrations of each extract at $37^{\circ} \mathrm{C}$ with shaking for $3 \mathrm{~h}$ and $24 \mathrm{~h}$, respectively. Following incubation, samples were 10-fold diluted in LB and plated on TSA to determine the number of CFU. Bactericidal activity was defined as a reduction of at least $3 \log _{10}$ in the number of viable bacteria as compared to the inoculum.

\section{Biofilm inhibition assay}

The S. epidermidis ATCC 35984 strain was cultured overnight and then diluted 1:1000 in TSB. Bacterial suspension was dispensed into wells of a flat-bottom polystyrene 96-well microplates (Corning Costar, Lowell, USA), in the presence of each extract or tannin compound used at the concentration of $1 / 2$ MIC. Bacteria incubated in the absence of the compounds represented negative controls. After a static incubation of the microplates at $37^{\circ} \mathrm{C}$ for $24 \mathrm{~h}$, biofilm biomass was quantified by crystal violet $(\mathrm{CV})$ staining assay. Briefly, biofilms were washed three times with phosphate-buffer saline (PBS), dried for $1 \mathrm{~h}$ at $60^{\circ} \mathrm{C}$ and incubated for $15 \mathrm{~min}$ with $1 \%(w / v) \mathrm{CV}$ (bioMérieux, Florence, Italy). The plates were extensively washed with PBS to remove the unbound $\mathrm{CV}$. Plates were then dried at $37^{\circ} \mathrm{C}$ for $30 \mathrm{~min}$. Biofilm-associated CV was extracted with $33 \%$ acid acetic (Sigma Aldrich) and measured by evaluating the optical density at $570 \mathrm{~nm}\left(\mathrm{OD}_{570}\right)$ in a microplate reader (Model 550, Bio-Rad Laboratories Srl, Italy).

\section{Statistical analysis}

Grafit 7 (Erithacus Software, London UK), and R 2.5.1 software ( $\mathrm{R}$ Foundation for Statistical Computing, Vienna), were used to statistical analysis. All analyses were performed in triplicate, if not differently stated.
Microbiological data are reported as mean \pm standard error of the mean of at least three independent experiments. The statistical significance of the data was evaluated by one-way ANOVA followed by Tukey-Kramer post hoc test. A $p$ value $<0.05$ was considered significant.

\section{Results \\ Phenolics content and antioxidant activity of Cytinus extracts}

To ascertain the chemical composition of C. hypocistis and $C$. ruber we used three sequential extraction steps with increasingly polar solvents to fractionate the freeze dried plants: cyclohexane, ethanol, and water. While in both cases the hydrophobic portion of the plant was minimal (data not shown), ethanol and water allowed significant recovery (Table 1). The polyphenolic component of the extracts was quantified, as well as total flavonoids and anthocyanins. For both Cytinus species the ethanolic extract was the richest fraction, with significantly more phenolics than the water analogue. Flavonoids accounted for only a small part of total phenolics, whereas no anthocyanins were detected (Table 1). Antioxidant was then determined using three different spectrophotometric electron transfer-based methods (TEAC-ABTS, FRAP, and DPPH-scavenging) and a HAT method (ORAC-PYR). In all cases, $C$. hypocistis extracts displayed a strongest antioxidant activity than $C$. ruber extracts, both when results were expressed as Trolox Equivalents $(\mathrm{mM} \mathrm{TE} / \mathrm{g})$ and as $\mathrm{IC}_{50}$ (Table 1).

Tyrosinase (or polyphenol oxidase PPO) is a wellknown enzyme involved in melanogenesis and food browning. The development of new inhibitors of this enzymatic activity is important in the perspective of application in food formulations as anti-browning agents. To avoid any interference with the tyrosinase inhibition tests, both mono- and di-phenolase activity was

Table 1 Total antioxidant capacity of Cytinus hypocistis and Cytinus ruber extracts

\begin{tabular}{|c|c|c|c|c|}
\hline \multirow[t]{2}{*}{ Assay } & \multicolumn{2}{|l|}{ Cytinus hypocistis } & \multicolumn{2}{|l|}{ Cytinus ruber } \\
\hline & Ethanol extract & Water extract & Ethanol extract & Water extract \\
\hline Amount (g/100 g of dried plant material) & $21 \%$ & $14 \%$ & $13 \%$ & $35 \%$ \\
\hline ORAC-PYR (mmol TE/g) & $9.1 \pm 1.4$ & $7.8 \pm 1.1$ & $7.5 \pm 1.2$ & $5.1 \pm 0.8$ \\
\hline DPPH (mmol TE/g) & $6.2 \pm 0.6$ & $4.5 \pm 0.1$ & $4.0 \pm 0.5$ & $2.6 \pm 0.2$ \\
\hline $\mathrm{DPPH}\left(\mathrm{IC}_{50} \mu \mathrm{g} / \mathrm{mL}\right)$ & $6.8 \pm 1.2$ & $8.2 \pm 0.4$ & $11.4 \pm 0.6$ & $15.8 \pm 0.7$ \\
\hline TEAC (mmol TE/g) & $11.2 \pm 0.8$ & $7.8 \pm 0.3$ & $6.5 \pm 0.7$ & $5.6 \pm 0.3$ \\
\hline TEAC $\left(I C_{50} \mu \mathrm{g} / \mathrm{mL}\right)$ & $83 \pm 9$ & $121 \pm 13$ & $140 \pm 15$ & $168 \pm 21$ \\
\hline FRAP (mmol TE/g) & $8.4 \pm 0.4$ & $5.2 \pm 0.6$ & $5.9 \pm 0.2$ & $3.8 \pm 0.1$ \\
\hline FRAP (mmol Fe"lg) & $9.3 \pm 0.9$ & $6.5 \pm 0.1$ & $5.2 \pm 0.3$ & $4.7 \pm 0.1$ \\
\hline Total phenolics (mmol GAE/g) & $12.2 \pm 0.1$ & $8.88 \pm 0.07$ & $9.57 \pm 0.09$ & $6.27 \pm 0.02$ \\
\hline Total flavonoids (mmol RE/g) & $0.48 \pm 0.01$ & $0.38 \pm 0.03$ & $0.51 \pm 0.04$ & $0.27 \pm 0.01$ \\
\hline Total anthocyanins (mg cyanidin 3-O-glucoside/g) & n.d. & n.d. & n.d. & n.d. \\
\hline
\end{tabular}

Data are expressed per gram of dry extract; n.d. not detectable 
ruled out in the Cytinus extracts tested using an ad hoc assay (see Methods). All the extracts were able to inhibit tyrosinase activity, albeit to different extents. Particularly, both the ethanolic and water extracts of $C$. hypocistis were more effective than the correspondent extracts of C. ruber (Table 2). In all cases, ethanolic extracts displayed the strongest anti-tyrosinase activity. The ethanolic extract of C. hypocistis had the lowest $\mathrm{IC}_{50}(9.8 \mu \mathrm{g})$, a value that almost doubled in the case of C. ruber $\left(\mathrm{IC}_{50} 16 \mu \mathrm{g}\right)$ (Table 2).

\section{Cytinus tannin profile}

Analysis of the extracts of C. hypocistis and C. ruber through HPLC and MS revealed that they contained a significant amount of gall tannins (Table 3). $\beta$-Glucogallin (1-O-galloyl- $\beta$-D-glucose) was particularly abundant, reaching almost $20 \mathrm{~g} / \mathrm{kg}$ in the water extract of $C$. hypocistis. In general, $C$. hypocistis extracts contained an higher amount of tannins with respect to $C$. ruber. We confirmed the presence of pentagalloyl-O- $\beta$-D-glucose in all extracts, which reached the concentration of $0.117 \mathrm{~g} / \mathrm{kg}$ in the ethanolic extract of $C$. hypocistis (Table 3). The only possible comparison can be made with a previous study of the chemical composition and cytotoxic properties of extracts of Cytinus collected in Grece [13]. In this work, samples of Cytinus ruber were analyzed and hydrolysable tannins (including 1,2,3,6-tetragalloyl-O- $\beta$-D-glucose and $1,2,3,4,6$-pentagalloyl-O- $\beta$-D-glucose) were identified as the main component [24]. In a further study, isoterchebin, another hydrolysable tannin of the ellagitannin class, was determined to be at the origin of the yellow pigment of C. hypocistis [26].

\section{Minimum inhibitory concentrations of Cytinus extracts}

The MIC values of aqueous and ethanolic extracts of both $C$. hypocistis and C. ruber against relevant pathogenic bacterial species were determined in MHB. Synthetic 1 -O-galloyl- $\beta$-D-glucose and penta-O-galloyl- $\beta$-D-glucose, whose presence was demonstrated in both Cytinus extracts, were also tested for their antimicrobial properties. All three Gram-positive bacterial species tested resulted sensitive to both Cytinus extracts (Table 4). In particular, aqueous extracts exhibited MICs ranging from 125 to $500 \mu \mathrm{g} / \mathrm{ml}$ whereas MICs of ethanolic extracts ranged from 31.25 to $250 \mu \mathrm{g} / \mathrm{ml}$ (Table 4). The compound penta-O-galloyl- $\beta$-D-glucose resulted active towards the same Gram-positive species with MIC values ranging from 31.25

Table 2 Anti-tyrosinase activity of Cytinus hypocistis and Cytinus ruber extracts

\begin{tabular}{lll}
\hline Species & Ethanol extract & Water extract \\
\hline Cytinus hypocystis & $9.8 \pm 0.7$ & $20 \pm 2$ \\
Cytinus ruber & $16 \pm 2$ & $33 \pm 6$ \\
\hline
\end{tabular}

Data expressed as $\mathrm{I}_{50}(\mu \mathrm{g})$ to $62.5 \mu \mathrm{g} / \mathrm{ml}$, whereas 1 -O-galloyl- $\beta$-D-glucose was inactive up to the concentration of $500 \mu \mathrm{g} / \mathrm{ml}$. In contrast to the Gram-positive bacteria, any of the extracts tested up to $500 \mu \mathrm{g} / \mathrm{ml}$ was able to inhibit the growth of the two Gram-negative species (Table 4).

\section{Bactericidal activity of Cytinus extracts}

The bactericidal activity of the aqueous and ethanolic extracts of $C$. hypocistis and $C$. ruber as well as of synthetic penta-O-galloyl- $\beta$-D-glucose was evaluated against S. aureus ATCC 33591 and S. epidermidis ATCC 35984 in SPLB. As shown in Fig. 3, after $24 \mathrm{~h}$ of incubation all the extracts tested resulted bactericidal against both bacterial species causing approximately 3 Logs reduction in the number of viable cells at concentrations ranging from 62.5 to $250 \mu \mathrm{g} / \mathrm{ml}$. At such concentrations, the killing effect was evident also at $3 \mathrm{~h}$ of incubation with reductions in the number of CFUs ranging from 1 and 3 Logs depending on the extract and the bacterial species tested. Synthetic penta-O-galloyl- $\beta$-D-glucose was bactericidal against $S$. aureus at $3 \mathrm{~h}$ incubation, while only an 1.5 Log reduction in the number of CFU at $24 \mathrm{~h}$ was recorded against $S$. epidermidis.

\section{Anti-biofilm activity of Cytinus extracts against $S$. epidermidis}

Next, we investigated the ability of $C$. hypocistis and $C$. ruber extracts as well as of the two synthetic phytochemicals 1-O-galloyl- $\beta$-D-glucose and penta-O-galloyl$\beta$-D-glucose to inhibit the formation of biofilms of $S$. epidermidis, one of the major nosocomial pathogens, often involved in medical device-associated infections [27]. Ability of the bacterium to colonize and form biofilms on a variety of biotic and abiotic surfaces is regarded as one of the main virulence factor of such bacterial species urging the identification of new antimicrobials with anti-biofilm potential [28]. The biofilm inhibitory effect was assessed after $24 \mathrm{~h}$ incubation with Cytinus extracts by CV staining, a technique that allows the evaluation of the total biofilm biomass (extracellular matrix and biofilm-associated cells). As shown in Fig. 4, ethanolic extract of both C. hypocistis and C. ruber, tested at sub-inhibitory concentrations (1/2 MIC), caused an inhibitory effect in biofilm formation of 80 and $60 \%$, respectively as compared to the control biofilms (cells incubated in medium only). In contrast, water extracts of both Cytinus species did not display a statistically significant reduction of biofilm biomass (Fig. 4) at the tested concentrations. Penta-O-galloyl- $\beta$-D-glucose was able to cause a reduction of biofilm formation of approximately $45 \%$, whereas 1 -O- $\beta$-D-galloyl-glucose was completely inactive (data not shown). 
Table 3 Levels of tannins in Cytinushypocistis and Cytinusruber extracts ( $\mathrm{g} / \mathrm{kg}$ )

\begin{tabular}{|c|c|c|c|c|}
\hline Tannin & Cytinus hypocistis (Ethanol) & Cytinus hypocistis (Water) & Cytinus ruber (Ethanol) & Cytinus ruber (Water) \\
\hline 1-O-galloyl- $\beta-D$-glucose & 9.991 & 19.292 & 2.608 & 1.994 \\
\hline di-O-galloyl- $\beta-D-g l u c o s e$ & 0.281 & 0.846 & 0.054 & 0.119 \\
\hline tri-O-galloyl- $\beta-D-g l u c o s e$ & 0.255 & 0.316 & 0.145 & 0.057 \\
\hline tetra-O-galloyl- $\beta$-D-glucose & 0.670 & 0.078 & 0.637 & 0.060 \\
\hline penta-O-galloyl- $\beta$-D-glucose & 0.117 & 0.073 & 0.043 & 0.195 \\
\hline Tellimagradin & 0.063 & 0.039 & - & - \\
\hline
\end{tabular}

$\mathrm{CV}<5 \%$

\section{Discussion}

Cytinus hypocistis and C. ruber are the only two species of this genus present in the Mediterranean area. These parasitic plants are easily distinguished in the field: $C$. hypocistis has bright yellow flowers while $C$. ruber has flowers with crimson or bright-red scale leaves and bracts, and an ivory-white or pale pink perianth (Figs. 1 and 2). Moreover, the two species occupy different ecological niches, as C. hypocistis is parasitic on whiteflowered Cistus species (like C. monspeliensis and C. salviifolius), whereas C. ruber occurs on pink-flowered Cistus (for example C. creticus and C. albidus) [29-31]. Plants have developed sophisticated defense mechanisms that allow them to survive in their ecosystems, and hence, they represent a rich source of antimicrobial agents and other compounds of pharmaceutical interest [32, 33]. Over the past decade, the efficacies of several plant derived inhibitors have been investigated to determine their antimicrobial potential and ability to reduce the formation of biofilms of staphylococci [34-36] and other pathogenic bacteria. The results of antimicrobial assays of both Cytinus extracts are consistent with previous studies investigating the antimicrobial activity of tannin-rich plant extracts or penta-O-galloyl- $\beta$-D-glucose that reported a higher susceptibility of Gram-positive bacteria than Gram-negative bacteria to such extracts/ compounds [37, 38]. It has been suggested that the antimicrobial activity of gallo tannins maybe related to their action on the membranes of the bacteria and/or their ability to complex metal ions [39, 40]. The poor antimicrobial activity of tannins against Gram-negative bacteria has been previously attributed to the strong repulsive negative charge of lipopolysaccharides [41]. Furthermore, the bactericidal effect displayed by the Cytinus extracts may be due to the presence of tannins, for which a killing activity was previously reported [39, 42, 43].

Relevant to the present investigation, gallo tannins have been identified as a significant part of plants' active components, playing multiple roles. More specifically, penta-O-galloyl- $\beta$-D-glucose raised considerable interest because of its valuable functional properties and potential application as an antimicrobial, anti-inflammatory, antidiabetic and antioxidant agent [44-46]. Besides being active against Gram-positive bacterial strains in planktonic form, penta-O-galloyl- $\beta$-D-glucose, either in a solution or coated on solid surfaces, was shown to be able to inhibit biofilm formation by $S$. aureus by inhibiting bacterial attachment and formation of polysaccharide intercellular adhesin [45]. In the present study, we demonstrated for the first time the suppressive activity of ethanolic extracts of $C$. hypocistis and C. ruber on biofilm formation of $S$. epidermidis. Interestingly, the antibiofilm activity was observed at sub-inhibiting concentrations, suggesting that the inhibitory effect is not

Table 4 Antimicrobial activities of water and ethanolic extracts of Cytinus against Gram-positive and Gram-negative bacteria

\begin{tabular}{|c|c|c|c|c|c|c|}
\hline \multirow[b]{2}{*}{ Bacterial strains } & \multicolumn{2}{|c|}{ Cytinus hypocistis } & \multicolumn{2}{|l|}{ Cytinus ruber } & \multirow{2}{*}{$\begin{array}{l}\text { 1-O-galloyl- } \\
\beta \text {-D-glucose }\end{array}$} & \multirow{2}{*}{$\begin{array}{l}\text { penta-O- } \\
\text { galloyl- } \beta \text { - } \\
\text { D-glucose }\end{array}$} \\
\hline & Water extract & Ethanolic extract & Water extract & Ethanolic extract & & \\
\hline \multicolumn{7}{|l|}{ Gram-positive } \\
\hline S. aureus ATCC 33591 & 500 & 125 & 250 & 125 & $>500$ & 62.5 \\
\hline S. epidermidis ATCC 35984 & 500 & 250 & 250 & 250 & $>500$ & 62.5 \\
\hline E. faecium VanR 1 & 125 & 31.25 & 125 & 31.25 & $>500$ & 31.25 \\
\hline \multicolumn{7}{|l|}{ Gram-negative } \\
\hline P. aeruginosa ATCC 29534 & $>500$ & $>500$ & $>500$ & $>500$ & $>500$ & $>500$ \\
\hline K. pneumoniae (ATCC BAA-1706) & $>500$ & $>500$ & $>500$ & $>500$ & $>500$ & $>500$ \\
\hline
\end{tabular}

Data reported represent minimal inhibitory concentrations (MIC) values expressed in $\mu \mathrm{g} / \mathrm{ml}$ 


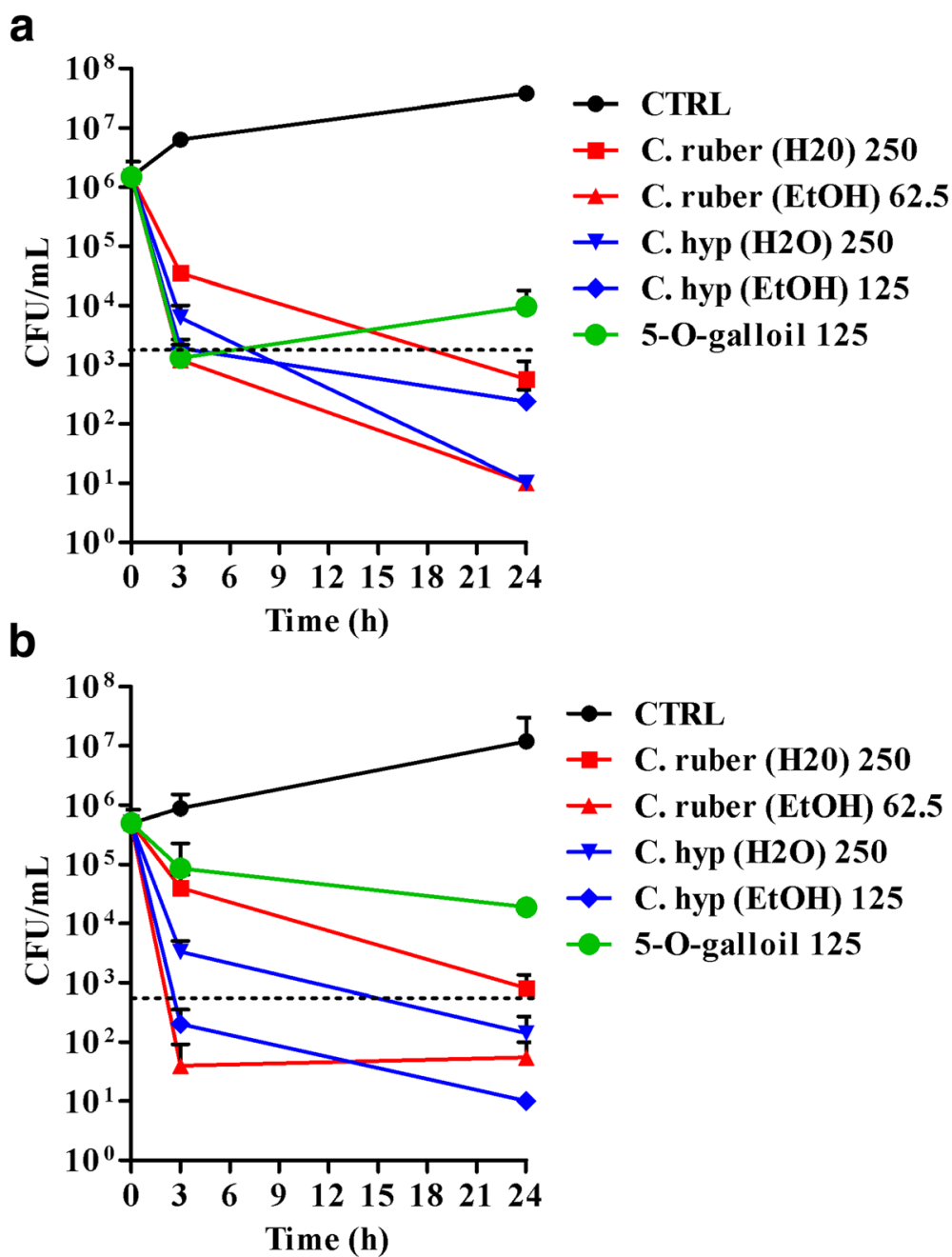

Fig. 3 Killing kinetics of Cytinus hypocystis and Cytinus ruber extracts (at concentrations ranging from 62.5 to $250 \mu \mathrm{g} / \mathrm{ml}$ ) and penta-O-galloyl- $\beta-D-$ glucose (abbreviated as 5-O-galloyl in the graphs, 125 mg/ml) against S. aureus ATCC 33591 (a) and S. epidermidis ATCC 35984 (b). Bacteria were incubated in sodium-phosphate buffer 10 mM, pH 7.4 supplemented with $2 \%$ LB in the presence of the antimicrobial compounds for 3 and $24 \mathrm{~h}$. Control (CTRL) represents untreated bacteria. Dashed line represent 3 Logs reduction in CFU count as compared to inoculums. The numbers in the figure legend are the concentrations used expressed in $\mu \mathrm{g} / \mathrm{ml}$. Data are expressed as mean \pm standard error of at least three independent experiments

due to a direct antibacterial effect, but rather to a more specific anti-biofilm mechanism [47]. Previous studies demonstrated that tannins - that occur abundantly in Cytinus extracts - are able to inhibit the formation of $S$. aureus biofilms by repressing the ica operon, which regulates the synthesis of the biofilm extracellular polysaccharides [48]. The ica operon is also present in $S$. epidermidis ATCC 35,984 and has an important role in biofilm formation $[49,50]$. Thus, it can be presumed that Cytinus extracts may repress biofilm formation of $S$. epidermidis by inhibiting the synthesis of extra cellular polysaccharides. While no major difference was observed in antibacterial and antibiofilm activity between C. hypocystis and C. ruber extracts, overall the ethanolic Cytinus extracts resulted more active than water extracts in anti-bacterial and anti-biofilm activity. Such difference may be due to the higher phenolic and flavonoid content in ethanolic extracts than water extracts. In addition, it has to be taken into account that additive and/or synergistic effects of multiple phytochemicals can be present in plant extracts [51]. In this regard, further studies will be needed to identify the most effective anti-bacterial combinations of phytochemicals contained in Cytinus extracts. The control experiments performed during our investigation by using synthetic gall tannins permit to conclude that penta-O-galloyl- $\beta$-D-glucose, present in all Cytinus extracts, is an active component, while the abundant 1-O-galloyl- $\beta$-D-glucose proved deprived of any activity. 


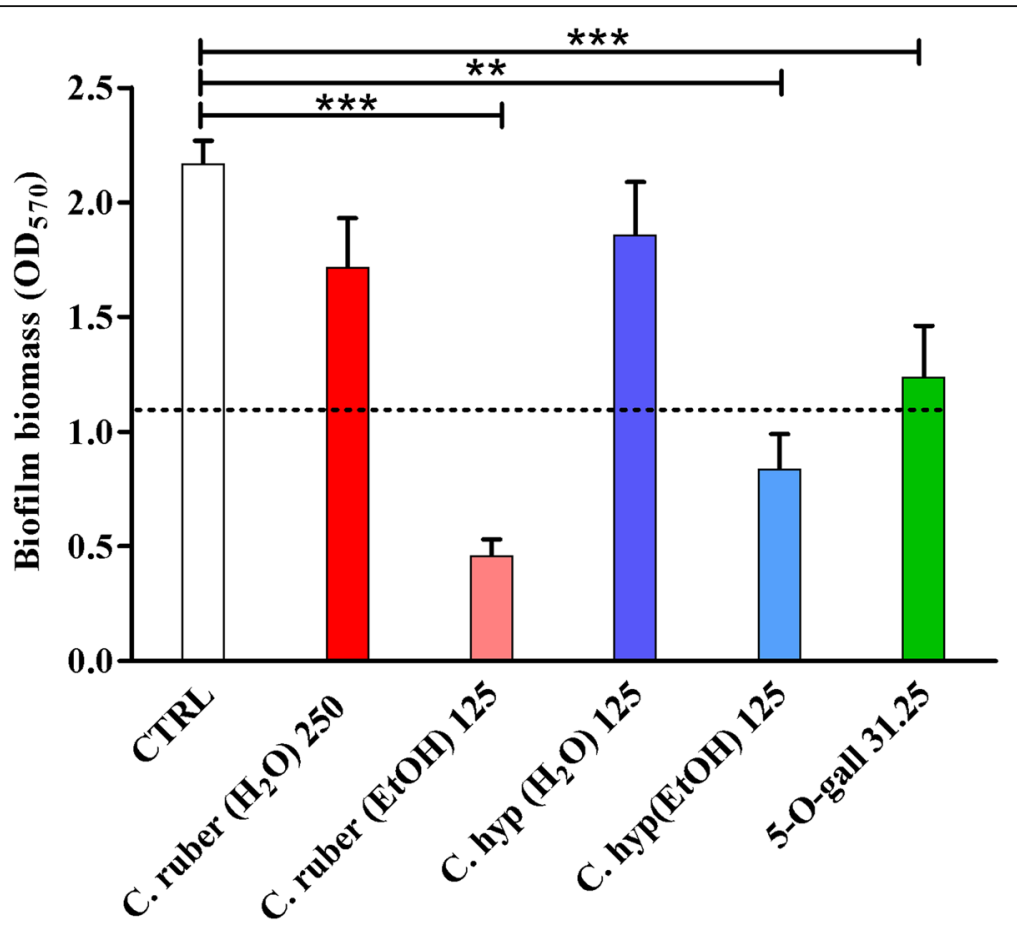

Fig. 4 Inhibitory effect of Cytinus hypocystis and Cytinus ruber extracts (at concentrations ranging from 125 to $250 \mu \mathrm{g} / \mathrm{ml}$ ) and penta-O-galloyl- $\beta$ D-glucose (abbreviated as 5-O-gall in the graph; $31.25 \mu \mathrm{g} / \mathrm{ml}$ ) on biofilm formation of S. epidermidis ATCC 35984 . The inhibitory effect was assessed by measuring the total biofilm biomass by crystal violet staining after $24 \mathrm{~h}$ of incubation with the extracts. Control (CTRL) represents untreated bacteria. Concentrations are expressed in $\mu \mathrm{g} / \mathrm{mL}$. Dashed lines represent $50 \%$ reduction in biofilm biomass as compared to untreated controls. Data are reported as mean \pm standard error of at least three independent experiments. $* * p<0.01 ; * * * p<0.001$ (one-way ANOVA followed by Tukey-Kramer post hoc test)

\section{Conclusions}

Overall, the results obtained in the present work reveal a high antibacterial and anti-biofilm efficacy of $C$. hypocistis and C. ruber extracts against Gram-positive human pathogens, therefore such extracts may be ranked among natural agents with promising therapeutic potential.

\section{Abbreviations}

ABTS: 2,2'-azinobis (3-ethylbenzothiazoline 6-sulphonate); ADA: 4-amino-N,Ndiethylaniline; APH: 2,2'-azobis (2-amidinopropane) dihydrochloride: CFU: Colony forming unit; CV: Crystal violet; DPPH: 1,1-Diphenyl-2picrylhydrazyl; ESI: Electrospray ionization; FRAP: Ferric Reducing Antioxidant Power; LB: Luria -Bertani broth; MHB: Muller-Hinton broth; MIC: Minimal inhibitory concentration; MS: Mass spectrometry; ORAC-PYR: Oxygen Radical Absorbance Capacity-Pyrogallol red; SPB: Sodium phosphate buffer $10 \mathrm{mM}$ pH 7.4; SPLB: SPB supplemented with 2\% LB; TBC: 4-tert-butylcatechol; TEAC: Trolox Equivalent Antioxidant Capacity; TOF: Time of flight; TSA: Tryptone Soy Agar; TSB: Tryptone Soy broth
}

\section{Acknowledgments}

Authors would like to thank Kodjo Eloh for performing TOF analyses.

\section{Funding}

This research was partially supported by a grant from the University of Pisa (PRA 2017_18). The founding sponsor had no role in the study design, performance, data collection and analysis, decision to publish, or preparation/writing of the manuscript.

\section{Availability of data and materials}

All the data obtained and materials analyzed in this research are available with the corresponding author upon request.

\section{Authors' contributions}

Conceptualization, ACR, PZ, and GB; Methodology, GM, PZ, and PC; Formal Analysis, GM, GB, SE, PC, PZ, and ACR; Writing-Original Draft Preparation, ACR, GM, PZ, PC, SE, GB; Writing-Review \& Editing, ACR, GM; Supervision, ACR, GM. All authors read and approved the final manuscript.

Ethics approval and consent to participate

Not applicable because we did not work with animals or humans.

Consent for publication

Not applicable for this submission.

Competing interests

The authors declare that they have no competing interests.

\section{Publisher's Note}

Springer Nature remains neutral with regard to jurisdictional claims in published maps and institutional affiliations.

\section{Author details}

'Department of Translational Research and New Technologies in Medicine and Surgery, University of Pisa, Pisa, Italy. ${ }^{2}$ Department of Life and Environmental Sciences, University of Cagliari, 09124 Cagliari, Italy. ${ }^{3}$ Department of Biomedical Sciences, University of Cagliari, Cittadella Universitaria, 09042 Monserrato (CA), Italy. 


\section{Received: 16 October 2018 Accepted: 21 March 2019} Published online: 05 April 2019

\section{References}

1. Puupponen-Pimiä R, Nohynek L, Meier C, Kähkönen M, Heinonen M, Hopia A, Oksman-Caldentey KM. Antimicrobial properties of phenolic compounds from berries. J Appl Microbiol. 2001;90:494-507.

2. Dai J, Mumper RJ. Plant phenolics: extraction, analysis and their antioxidant and anticancer properties. Molecules. 2010;15:7313-52.

3. Działo M, Mierziak J, Korzun U, Preisner M, Szopa J, Kulma A. The potential of plant phenolics in prevention and therapy of skin disorders. Int J Mol Sci. 2016;17:160.

4. The Plant List (2010). Version 1. (Accessed 1 Jan). http://www.theplantlist. org/browse/A/Cytinaceae/Cytinus

5. Nickrent DL. The parasitic plant connection, Cytinaceae. Carbondale: Southern Illinois University; 1997. http://parasiticplants.siu.edu/.

6. Burgoyne PM. A new species of Cytinus (Cytinaceae) from South Africa and Swaziland, with a key to the Southern African species. Novon. 2006;16:315-9.

7. Thorogood CJ, Hiscock SJ. Host specificity in the parasitic plant Cytinus hypocistis. Res Lett Ecol. 2007;2007:1-4.

8. U.S. Department of Agriculture, Agricultural Research Service. Dr. Duke's Phytochemical and Ethnobotanical Databases. https://phytochem.nal.usda. gov/phytochem/ethnoPlants/show/3003?qlookup=wolfsbane\&offset= $0 \& \max =20 \&$ et.

9. Zucca P, Pintus M, Manzo G, Nieddu M, Steri D, Rinaldi AC. Antimicrobial, antioxidant and anti-tyrosinase properties of extracts of the Mediterranean parasitic plant Cytinus hypocistis. BMC Res Notes. 2015;8:562

10. Sanna C, Lancioni C, Colomo S. Guida alle piante medicinali della Sardegna, vol. 2. Nuoro: Editrice Archivio Fotografico Sardo; 2016

11. Loi MC, Frailis L, Maxia A. Le piante utilizzate nella medicina popolare nel territorio di Gesturi (Sardegna centro-meridionale). Atti Soc Tosc Sci Nat Mem Serie B. 2002;109:167-76.

12. Atzei AD. Le piante nella tradizione popolare della Sardegna. Sassari: Carlo Delfino; 2003.

13. Magiatis $P$, Pratsinis $H$, Kalpoutzakis $E$, Konstantinidou A, Davaris $P$, Skaltsounis AL. Hydrolyzable tannins, the active constituents of three Greek Cytinus taxa against several tumor cell lines. Biol Pharm Bull. 2001;24:707-9.

14. Fokialakis N, Kalpoutzakis E, Tekwani BL, Khan SI, Kobaisy M, Skaltsounis AL, Duke SO. Evaluation of the antimalarial and antileishmanial activity of plants from the Greek island of Crete. J Nat Med. 2007;61:38-45.

15. Zucca P, Argiolas A, Nieddu M, Pintus M, Rosa A, Sanna F, Sollai F, Steri D. A Rescigno. Biological activities and nutraceutical potentials of water extracts from different parts of Cynomorium coccineum L. (Maltese Mushroom). Pol J Food Nutr Sci. 2016;66:179-88.

16. Zucca P, Sanjust E, Trogu E, Sollai F, Rescigno A. Evaluation of antioxidant capacity of antioxidant-declared beverages marketed in Italy. It J Food Sci. 2010;22:313-9.

17. Zucca P, Rosa A, Tuberoso CIG, Piras A, Rinaldi AC, Sanjust E, Dessì MA, Rescigno A. Evaluation of antioxidant potential of "Maltese mushroom" (Cynomorium coccineum) by means of multiple chemical and biological assays. Nutrients. 2013;5:149-61.

18. Delazar A, Khodaie L, Afshar J, Nahar L, Sarker S. Isolation and free-radicalscavenging properties of cyanidin 3-O-glycosides from the fruits of Ribes biebersteinii, Berl. Acta Pharma. 2010;60:1-11.

19. Huang D, Ou B, Prior RL. The chemistry behind antioxidant capacity assays. J Agric Food Chem. 2005;53:1841-56.

20. Sollai F, Zucca P, Sanjust E, Steri D, Rescigno A. Umbelliferone and esculetin: Inhibitors or substrates for polyphenol oxidases? Biol Pharm Bull. 2008:31:2187-93.

21. Zucca P, Vinci C, Rescigno A, Dumitriu E, Sanjust E. Is the bleaching of phenosafranine by hydrogen peroxide oxidation catalyzed by silicasupported 5,10,15,20-tetrakis-(sulfonatophenyl) porphine-Mn (III) really biomimetic? J Mol Catal A Chem. 2010;321:27-33.

22. Zucca P, Rescigno A, Olianas A, Maccioni S, Sollai FA, Sanjust E. Induction, purification, and characterization of a laccase isozyme from Pleurotus sajorcaju and the potential in decolorization of textile dyes. J Mol Catal B Enzym. 2011;68:216-22.

23. Rescigno A, Zucca P, Flurkey A, Inlow J, Flurkey WH. Identification and discrimination between some contaminant enzyme activities in commercial preparations of mushroom tyrosinase. Enzyme Microb Technol. 2007:41:620-7.
24. Zucca P, Sanjust E, Loi M, Sollai F, Ballero M, Pintus M, Rescigno A. Isolation and characterization of polyphenol oxidase from Sardinian poisonous and non-poisonous chemotypes of Ferula communis (L.). Phytochemistry. 2013;90:16-24.

25. European Committee for Antimicrobial Susceptibility Testing (EUCAST) of the European Society of Clinical Microbiology and Infectious Diseases (ESCMID) EUCAST definitive document E. Def 1.2, May 2000: terminology relating to methods for the determination of susceptibility of bacteria to antimicrobial agents. Clin Microbiol Infect. 2000;6:503-8.

26. Schildknecht H, Herb R, Kunzelmann P. Die Chemie der Schmarotzerblumen, II. Isoterchebin: Struktur des gelben EllagitanninFarbstoffesaus Cytinus hypocistis (Rafflesiaceae). Liebigs Ann Chem. 1985; 1985:1448-56.

27. Gomes F, Teixeira P, Oliveira R. Mini-review: Staphylococcus epidermidis as the most frequent cause of nosocomial infections: old and new fighting strategies. Biofouling. 2014;30:131-41.

28. Fey PD, Olson ME. Current concepts in biofilm formation of Staphylococcus epidermidis. Future Microbiol. 2010;5:917-33.

29. Govaerts R, Nickrent DL. 658. Cytinus ruber. Cytinaceae. Curtis's Bot Mag. 2010;26:314-21.

30. Roquet C, Coissac É, Cruaud C, Boleda M, Boyer F, Alberti A, Gielly L, Taberlet P, Thuiller W, Van Es J, Lavergne S. Understanding the evolution of holoparasitic plants: the complete plastid genome of the holoparasite Cytinus hypocistis (Cytinaceae). Ann Bot. 2016;118:885-96.

31. Thorogood C. Field guide to the wild flowers of Western Mediterranean. Kew: Kew Publishing; 2016.

32. Cowan MM. Plant products as antimicrobial agents. Clin Microbiol Rev. 1999;12:564-82.

33. Li JW, Vederas JC. Drug discovery and natural products: end of an era or an endless frontier? Science. 2009;325:161-5.

34. Kuźma L, Rózalski M, Walencka E, Rózalska B, Wysokińska H. Antimicrobial activity of diterpenoids from hairy roots of Salvia sclarea L.: salvipisone as a potential anti-biofilm agent active against antibiotic resistant Staphylococci. Phytomedicine. 2007;14:31-5.

35. Stenz L, François P, Fischer A, Huyghe A, Tangomo M, Hernandez D, Cassat J, Linder P, Schrenzel J. Impact of oleic acid (cis-9-octadecenoic acid) on bacterial viability and biofilm production in Staphylococcus aureus. FEMS Microbiol Lett. 2008;287:149-55.

36. Payne DE, Martin NR, Parzych KR, Rickard AH, Underwood A, Boles BR. Tannic acid inhibits Staphylococcus aureus surface colonization in an IsaAdependent manner. Infect Immun. 2013;81:496-504.

37. Engels C, Schieber A, Gänzle MG. Inhibitory spectra and modes of antimicrobial action of gallotannins from mango kernels (Mangifera indica $\mathrm{L}$. ). Appl Env Microbiol. 2011;77:2215-23.

38. Tian F, Li B, Ji B, Zhang G, Luo Y. Identification and structure-activity relationship of gallotannins separated from Gallachinensis. LWT Food Sci Technol. 2009:42:1289-95.

39. Chung KT, Lu Z, Chou MW. Mechanism of inhibition of tannic acid and related compounds on the growth of intestinal bacteria. Food Chem Toxicol. 1998;36:1053-60.

40. Engels C, Knödler M, Zhao YY, Carle R, Gänzle MG, Schieber A. Antimicrobial activity of gallotannins isolated from mango (Mangifera indica L.) kernels. J Agric Food Chem. 2009;57:7712-8.

41. Yoda Y, Hu Z-H, Zhao W-H, Shimamura T. Different susceptibilities of Staphylococcus and gram-negative rods to epigallocatechin gallate. J Infect Chemother. 2004;10:55-8.

42. Adnan SN, Ibrahim N, Yaacob WA. Disruption of methicillin-resistant Staphylococcus aureus protein synthesis by tannins. Germs. 2017;7:186-92.

43. Chusri S, Voravuthikunchai SP. Damage of staphylococcal cytoplasmic membrane by Quercus infectoria G. Olivier and its components. Lett Appl Microbiol. 2011:52:565-72.

44. Piao X, Piao X-L, Kim HY, Cho EJ. Antioxidative activity of geranium (Pelargonium inquinans Ait) and its active component, 1,2,3,4,6-penta-O-

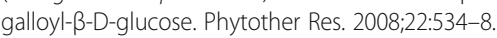

45. Lin M-H, Chang F-R, Hua M-Y, Wu Y-C, Liu S-T. Inhibitory effects of 1,2,3,4,6penta-O-galloyl- $\beta$-D-glucopyranose on biofilm formation by Staphylococcus aureus. Antimicrob Agents Chemother. 2011;55:1021-7.

46. Torres-León C, Ventura-Sobrevilla J, Serna-Cock L, Ascacio-Valdés JA, ContrerasEsquivel J, Aguilar CN. Pentagalloylglucose (PGG): a valuable phenolic compound with functional properties. J Funct Foods. 2017;37:176-89. 
47. Batoni G, Maisetta G, Esin S. Antimicrobial peptides and their interaction with biofilms of medically relevant bacteria. Biochim Biophys Acta. 2016; 1858:1044-60.

48. Lee JH, Park JH, Cho HS, Joo SW, Cho MH, Lee J. Anti-biofilm activities of quercetin and tannic acid against Staphylococcus aureus. Biofouling. 2013;29:491-9

49. O'Gara JP. ica and beyond: biofilm mechanisms and regulation in Staphylococcus epidermidis and Staphylococcus aureus. FEMS Microbiol Lett. 2007;270:179-88.

50. Brancatisano FL, Maisetta G, Di Luca M, Esin S, Bottai D, Bizzarri R, Campa M, Batoni $\mathrm{G}$. Inhibitory effect of the human liver-derived antimicrobial peptide hepcidin 20 on biofilms of polysaccharide intercellular adhesin (PIA)-positive and PIA-negative strains of Staphylococcus epidermidis. Biofouling. 2014;30:435-46.

51. Sánchez-Chávez AC, Salazar-Gómez A, Zepeda-Vallejo LG, Hernández de Jesús ML, Quintos-Escalante M, Vargas-Díaz ME, Luna-Herrera J. Trixis angustifolia hexanic extract displays synergistic antibacterial activity against M. tuberculosis. Nat Prod Res. 2017;25:1-5.

52. Thomé OW. Flora von Deutschland, Österreich und der Schweiz. Gera, Germany; 1885.

Ready to submit your research? Choose BMC and benefit from:

- fast, convenient online submission

- thorough peer review by experienced researchers in your field

- rapid publication on acceptance

- support for research data, including large and complex data types

- gold Open Access which fosters wider collaboration and increased citations

- maximum visibility for your research: over $100 \mathrm{M}$ website views per year

At BMC, research is always in progress.

Learn more biomedcentral.com/submissions 